\title{
6360 Sayılı Kanun Sonrası Yerel Siyasal Elitlerin Değișimi
}

\author{
Change of Local Political Elites After Law No. 6360
}

\author{
Abdullah AYDIN \\ Dr. Ögrr. Üyesi, Hatay Mustafa Kemal Üniversitesi, \\ IIBF, Uluslararası İlişkiler Bölümü, \\ abdullahaydin01@hotmail.com \\ https://orcid.org/0000-0002-1785-4999
}

Makale Başvuru Tarihi: 30.08 .2019
Makale Kabul Tarihi: 22.09.2019
Makale Türü: Araştırma Makalesi

ÖZET

Anahtar
Kelimeler:

6360 Sayılı

Kanun,

Yerel Demokrasi,

Elit Teorisi,

Yerel Elitler,

Keywords:

Law No. 6360,

Local Democracy,

Elite Theory,

Local Elites,
Elit kavramı gün geçtikçe, yani demokratik kurumlar yerine oturdukça değişime uğramıştır. Yerel yönetimler bağlamında değerlendirildiğinde, ilk başta toprak ve soy bazlı bir elit mantığl varken daha sonra ekonomik güç bazlı bir elit anlayışı gelişmiştir. Akabinde demokratikleşme neticesinde siyasal elitler veya demokratik elitler devreye girmiştir. Türkiye'de uzun bir süre yerel elitlerden bahsetmek mümkün olmamıştır. Ancak özellikle 1963 yılı ile yerel seçimlerin demokratik bir ortamda gerçekleşmesi merkeze ve diğer güç odaklarına karşı yeni bir gücün oluşmasına veya mevcut güçlerin siyasal olarak dönüşmesine neden olmuştur. Artık siyasal alanda söz sahibi olmak da bir elitlik sebebine dönüşmüştür. Kent kimliğinin bir parçası olan soylu, köklü ve zengin gruplar kümesinden meydana gelen elitlerin yanına sayıca fazla olan gruplar kümesi de eklemiştir. Çalışmanın temel amacı 6360 sayll yasa kapsamında yaşanan değişiklikleri ortaya koymak ve yasanın Türkiye'deki yerel elitler bağlamında oluşturduğu değişimi ortaya koymaktır. Bunu yaparken elit kavramı üzerinde durularak, siyasal elit kavramının tarihsel gelişimi ve yerele yansımaları ele alınmıştır. Akabinde Türkiye'deki yerel yönetimlerin durumu ve 6360 sayıl kanun ile ortaya çıkan durum anlatılarak kanun çerçevesinde yerel elitlerdeki değişim boyutları ve kapsamı çizilmiştir. Sonuç ve değerlendirme kısmı ile de bu durumun Türk yerel demokrasisi açısından oluşturduğ $u$ olumlu ve olumsuz durumlar ortaya konarak, sorun ve çözüm önerileri yapılmıştır.

\section{ABSTRACT}

Elite concept have changed day by day, that is, democratic institutions have changed. In the context of local governments, firstly there was an elite logic based on land and lineage, and then developed an economic power based elite understanding. Subsequent democratization resulted in political elites or democratic elites. For a long time in Turkey has not been able to talk about the local elite. However, the fact that the local elections took place in a democratic environment in 1963 led to the emergence of a new power against the center and other power centers or the political transformation of the existing forces. Having a say in the political sphere has also turned into a cause of elitism. He also added a large number of groups of elites close to the elite, a group of noble, deep-rooted and rich groups who were part of the urban identity. The main objective of the study was to determine the changes that took place within the scope of law numbered 6360 and reveals the changes brought about by the law in the context of the local elite in Turkey. In doing so, the elite concept was elaborated and the historical development of the concept of political elite and its reflections were discussed. Subsequently, the status of local governments in Turkey and the size and scope of change in the local elite as a result of the law was drawn up by explaining the Law No. 6360. With the conclusion and evaluation part, the problems and solution suggestions were made by revealing the positive and negative acpects that this situation created for Turkish local democracy. 


\section{GIRISS}

Batı dünyasında modern hayatın ortaya çıkması ile bir ihtiyaca dönüşen yerel ve kentsel hizmetlerin merkezi yönetimin dışında bir yerel yönetim birimi eliyle bütünleşik bir şekilde yapılması ihtiyacı yerel yönetimleri ortaya çıkartan en büyük nedendir. Bu hizmetleri talep edenler Batı aristokrasisine karşı gelişen burjuvazi ${ }^{1}$ oluşumuna öncülük etmiştir. Burjuvazi kendisi için gerekli kaynakları (sermaye, hammadde, işgücü vb.) kolay elde edebilmek ve o kaynakların konforunu sağlamak adına devletten belli hizmetler talep etmiştir. Her ne kadar aristokrasi direniş ile karşılaşsa da yerel hizmetlerin yerine getirilmesinde etkin olan yönetimler kurulmuştur. $\mathrm{Bu}$ bağlamda demokrasinin önünde bir sorun gibi duran elitlerin en azından yerleşik olan bir elit grubu devirmek için güç merkezi olarak devreye girmesi o eliti demokrasinin yerleşmesi açısından hızlandırıcı bir etki yapmasına neden olmuştur. Diğer yandan eğer eski elitler devrilip yerine yenileri oturup tunçlaşma yoluna giderlerse, yeni bir elitin ortaya çıkarak toplumu konsolide etmesi ve bu yol ile o grubu devirmesi gerekmektedir. $\mathrm{Bu}$ cihette yeni bir grubun yükselerek tunçlaşmışlara karşı direnç göstermesi kısa vadede demokratik bir durumken uzun vadede sadece bir dairesel hareketin parçası durumuna gelmektedir.

Yerel yönetimler çerçevesinde değerlendirildiğinde ise yerel yönetimlerin ortaya çıkması denildiğinde aynı şekilde akla ilk gelen şey yeni yerel elitler olarak değerlendirilebilir. Bu elitler gün geçtikçe, yani demokratik kurumlar yerine oturdukça değişime uğramıştır. Yerel yönetimler bağlamında değerlendirildiğinde, ilk başta toprak ve soy bazlı bir elit mantı̆̆ 1 varken daha sonra ekonomik güç bazlı bir elit anlayışı gelişmiştir. Akabinde demokratikleşme neticesinde siyasal elitler veya demokratik elitler devreye girmiştir.

Siyasal elitler için en çok dikkat çeken nokta genel olarak başkent esaslıymış gibi algılanmalarıdır. Yani merkezi yönetimi elinde tutanlar, belli bir siyasal elitin olmas1 -velev ki yerelden gelen temsilciler olsun- ve o temsilcilerin de sürekli olarak aynı çevre veya gruplardan olması gibi durumlar söz konusu olmuştur. Ancak bu durum yerelde de mevcuttur. Yani yereldeki yöneticilerin sürekli belli mensubiyetlerinin olması demokrasi açısından büyük sorun teşkil etmektedir. Bu bağlamda değerlendirildiğinde her ne kadar Türk yerel yönetim tarihi açısından gün be gün daha demokratik hakların elde edildiği anlayışı söz konusu olsa da bu değişimi dip bir dalga ile geldiğini söylemek zordur. Türkiye'de modernleşme sürecinde gerçekleşen her bir reform tepeden inmeci bir mantık ile yapılmıştır. Bu sebeple Türkiye'de demokratik kültürün oturmaması durumu söz konusudur. Başta ifade edildiği gibi bir dip hareketin mevcut duruma itiraz ederek halkı bir araya getirmemesi yüzünden Türkiye'de uzun bir süre modern manada yerel elitlerden bahsetmek mümkün olmamıştır. Ancak özellikle 1963 yılı ile yerel seçimlerin tam olarak demokratik bir ortamda gerçekleşmesi merkeze ve diğer güç odaklarına karşı yeni bir gücün oluşmasına veya mevcut güçlerin siyasal olarak dönüşmesine neden olmuştur. Artık siyasal alanda söz sahibi olmak da bir elitlik sebebine dönüşmüştür.

Kent kimliğinin bir parçası olan soylu, köklü ve zengin gruplar kümesinden meydana gelen elitlerin yanına sayıca fazla olan gruplar kümesi de eklemiştir. Çünkü demokrasinin en büyük çıktısı yüksek oydur. Yüksek oyun elde edilebilmesi içinde sayıca çoğunluğa sahip olan grupların desteğinin alınması gerekmektedir. Belli grupların oyları ile yerelde iktidara gelen yöneticiler belediye hizmetlerinin yerine getirilmesi noktasında bazı sorunlar ile karşı karşıya kalmaktadır. Çünkü yeniden seçilebilmesi için desteğine ihtiyaç duydukları sosyal grupların, mevcut desteklerine karşılık belediyeden muhtelif beklentileri ortaya çıkmaktadır. Seçimlerde ortaya koyacakları destekler ise beklentilerinin karşılanma oranı ile orantılıdır. Tüm halka hitap eden belediye yönetimlerinin, kamusal hizmet üretimlerinde bu grupların öncelikli talepleri ile karşılaşması yeni sorunların ortaya çıkmasına neden olacaktır. Belediyenin coğrafi açıdan yerellik derecesi arttıkça bu sosyal/siyasal baskı daha çok hissedilmektedir. Bu çerçevede 6360 sayılı kanun ile büyükşehirlerde yerel elitlerin baskısının azaltılmasına yönelik bazı değişikliklere gidilmiştir. Öyle ki ilçe veya belde boyutunda siyasal elit sayılabilecek kesimler il merkezinin yani büyükşehir belediye yönetiminin tahakkümü altına girmişlerdir. Bu durum yerelde bir merkezileşmeye neden olmuştur ${ }^{2}$. Elbette ki yeni merkez, yeni elitleri de beraberinde getirecektir. Yine yeni merkez olması hasebiyle eskiden ilçe ve belde merkezinde çözülen işler il merkezlerinde çözülmek zorunda kalacak ve elitler ilçe merkezlerinden il merkezlerine doğru kayacaklardır. Ancak ilçe bazlı yerel elitlerin diğer ilçe merkezli elitler ile bir araya gelmesi oransal olarak etkinliklerini azaltacaktır. Belediye yönetimlerinin bu güç unsurları önündeki hareket kabiliyetleri ve etki düzeyleri artarken, yerel elitlerin etki düzeyleri de oransal

1 Birçok kaynakta burjuvazi terimi aynı zamanda kent elitleri manasında da kullanılmaktadır. Söz konusu tercihin temel nedeni modernizmin ortaya çıkartmış olduğu yeni elitlerin kentleşme ile beraber kentlerde alan buldukları ile alakalıdır. Bu durum Batı özelinde haklı bir tercihtir. Ancak bu tercih çalışmamız için geçerli değildir. Zira çalışmanın temel dayanaklarından biri Türkiye'deki durumdur.

2 Konu hakkında daha detaylı bilgi için Bknz.: Belli ve Aydın, 2017. 
olarak azalacaktır. Söz konusu durum demokratik açıdan bir takım sorunları beraberinde getirse de ilçe ve beldelerde tunçlaşmış yapıların kırılması ihtimali bağlamında önem arz etmektedir.

Çalışmada elit kavramı üzerinde durularak, siyasal elit kavramının tarihsel gelişimi ve yerele yansımaları ele alınmıştır. Türkiye'deki yerel yönetimlerin durumu ve 6360 sayılı kanun ile meydana gelen yeni hukuki yapı da ele alınarak kanun çerçevesinde yerel elitlerdeki değişimin kapsamı ve boyutlanı ortaya konulmuştur. Değerlendirme kısmı ile de bu durumun Türk yerel demokrasisi açısından oluşturduğu olumlu ve olumsuz sonuçları ortaya konulmuştur. Bu bağlamda ortaya çıkan sorunlara çözüm önerileri sunulmuştur.

\section{ELIT KAVRAMI}

Kelime kökeni bakımından 18. yüzyılın sonları Fransızcasında mevcut olan "élite" (seçim, seçilmiş) ile "electlire" ve "electe" sözcüklerine dayanmaktadır. Bu kelimeler ise bir Latince kelime olan "eligere" değişkeninden türemiştir (oxforddictionaries, 2019). Elit kelimesi günümüzde Türkçe'de kullanılan yerleşmiş bir sözcüktür. Bununla birlikte elit sözcügü yerine "seçkin" kelimesi de kullanılmaktadır. Bu çerçevede mevcut sözcük, TDK'da (2019); "Benzerleri arasında niteliklerinin yüksekliğiyle göze çarpan, üstün, mümtaz, güzide, mutena manasına geldiği gibi, bir toplumda saygın ve etkin mevkilerde bulunan ve toplumun eğitim, ekonomi, siyaset, askeriye, din, sanat vb. alanlartyla ilgili etkinliklerin denetimini elinde tutan (kişi veya grup)", şeklinde tanımlanmaktadır.

Elit kavramı genel olarak bir toplumdaki en zengin, en güçlü ve en iyi eğitimli sosyal grup (Cambridge, 2019) olarak ifade edilmektedir. Elitler, türdaşlarından geri kalanının varlığı üzerinde orantısız miktarda kontrol sahibi olan küçük bir grubu da ifade etmektedir. Elitlerin kendileri çok küçük bir anahtar oyuncular grubu tarafından ayarlanır. Bu kilit oyuncular birbiriyle örtüşen karmaşık siyasi, ekonomik ve askeri elit çevreler grubunun çekirdeğini oluştururlar (Urbandictionary, 2019). Ayrıca elitler, en iyi olduğu düşünülen ve en yüksek statüye sahip olan grupları da ifade etmektedir. Orta çağda Batıda, sadece elit erkeklere okuma ve yazma öğretilmesi gibi uygulamalar bu olgunun bir göstergesidir (Vocabulary, 2019). Elitler, bir toplumdaki en etkili ve prestijli tabakadır. Ayrıca elitler, belli bir alanda seçkin liderler olarak kabul edilen kişiler olarak da izah edilmektedir. Böylece politik, dini, bilimsel, ticari ve sanatsal elitlerden söz etmek mümkündür (Mondal, 2019).

Elit teorinin kökenleri en açık şekilde Gaetano Mosca (1858-1941), Vilfredo Pareto (1848-1923), Robert Michels (1876-1936) ve Max Weber (1864-1920) yazılarında yatmaktadır. Mosca (1939), küçük azınlıkların büyük çoğunlukların örgütlenme ve bir araya gelmelerinin yollarını engellemisini vurgulamıştır. Ayrıca Mosca (1939:51) "siyasal sınıf" kavramını siyasal elitler merkezli kullanmaktadır ve genellikle yönetilenlere yönettiklerine göre "belirli bir maddi, entelektüel, hatta ahlaki bir üstünlüğe" sahip olduğunu eklemiştir. Pareto (1935:2031-2034, 2051), elitlerin, sınırsız sosyal hareketliliği olan bir toplumda, en yetenekli ve hak eden bireylerden oluşacağını vurgulamaktadır. Ancak normal toplumlarda, elitler en çok iki siyasal yöntem, yani güç ve ikna etme biçimini kullanma konusunda usta olan ve genellikle kalıtsal refah ve aile bağlantıları gibi önemli avantajlardan yararlananlar olarak izah etmiştir. Pareto, Machiavelli'yi izleyerek, tilki ve aslanlara benzeyen alternatif yönetim elit türlerini çizmektedir. Michels (1915:27), verimli bir şekilde çalışabilmeleri için liderler ve uzmanlar için büyük organizasyonlara ihtiyaç duyan elitleri (oligarşiler) köklenmesini vurgulamıştır. Bu kişiler fonların kontrolü, bilgi akışlarındaki kontrol, ekonomik-makamsal yükselmelerdeki etkileri ve örgütsel işleyişin diğer yönlerini domine etmeleri özelliklerini kazandıkça gücü ellerinde yoğunlaştırmışlardır. Weber (1978:1414), siyasal bir eylemin her zaman "küçük sayılar ilkesi, yani küçük lider grupların üstün siyasal manevra kabiliyeti" ile belirlendiğini iddia etmektedir. Bunun yanında "Kitlesel devletlerde bu Sezarist unsur kaçınılmaz", olduğu ifadelerini kullanmaktadır.

Elit terimi ile ilgili yapılan tanımlamalar göstermektedir ki elitler, kendileri ya da kendileri dışındaki kişiler tarafından haklı veya haksız sebeplerle üstün görülmektedir. Bu da elitlerin, yöneten olma noktasında doğal bir hakları olduğu fikrini ortaya koymaktadır. Nitekim Auguste Comte, "...Bilim çağında toplumun bir elit bilim insanı tarafindan yönetilmesi gerektiğine " inanmaktadır (collinsdictionary, 2019). Ancak bu durum genel itibariyle siyasal elitler tarafından yürütülmektedir.

Özellikle siyaset biliminde genel kabul gören elit kavramı daha spesifik bir konuya atıfta bulunmaktadır. Bu durum toplumsal gücün -özellikle siyasal gücün- bir azınlığın elinde yoğunlaşmasıdır. Elitlerle ilgili teorik tartışmaların ve deneysel araştırmaların temelinde, Mosca'nın bu konudaki savı bulunumaktadır. Buna göre (1939:50): "Bütün toplumlarda, iki sınıf insan ortaya çıkmaktadır - yöneten bir sinıf ve yönetilen bir sinıf". Bu iki sınıftan yöneten kısmın sürekli farklı yöntemler kullanarak gücü elinde tutmaya devam ettiği anlayışına sahip olan Mosca, özellikle siyasal elitlerin demokratik yönetimlerdeki kilit rolünü ikinci planda değerlendirmiştir. 
Diğer yandan çeşitli kurumsal bağlamlardaki "işlevsel elitler" kavramı, toplumsal düzeyde güç sağlayan bir "yönetici" veya "siyasal" elitin fikrinden ayrılmalıdır (Akard, 2001). Yani halka başarılı düzeyde hizmet götüren elit ya da iyi yöneten elit, diğer elitler arasında daha işlevsel ve amacını yerine getiren bir durumda konuşlanması bağlamında yönetici ve siyasal elitlerden ayrılabilir. Ancak bu durum doğru bir sonuç doğurmayacaktır. Daha başarılı elit sınıflandırması elitlerin ne olduğu üzerinde kalmalı onların nasıl oldukları toplumun ve konuda çalışma yapanların değerlendirilmesine bırakılmalıdır.

Elit teorisi bağlamında değerlendirildiğinde, bir toplumun işlerini en iyi şekilde üyelerinden oluşan küçük bir alt küme ile ve modern toplumlarda böyle bir düzenlemenin kaçınılmaz olduğu teorik bakış açısı söz konusudur. $\mathrm{Bu}$ iki prensip ideolojik olarak müttefik ama mantıksal olarak ayrılabilir durumdadır. Elit teorisinin altında yatan temel normatif soru, herhangi bir grubun göreceli gücünün, göreceli büyüklüğünü geçip geçmemesi gerektiğidir. Bu yaklaşım, elit azınlıkların orantısız etkisinin Platon'un "koruyucu" yönetici sınıfında olduğu gibi, üstün bilgeliklerine veya erdemlerine dayanarak savunduğu eski Yunanistan'a dayanmaktadır. İngiliz aristokrasisinin Yunan öncüsü (aristokratia) “en iyi adamlar" (aristolar) tarafından yönetilmeye sevk edilmiştir. $\mathrm{O}$ dönemde elit kuralların savunmasının ardındaki ampirik varsayım, en iyi insan özelliklerinin eşit olmayan dağılımında dügümmlenmektedir (Maloy, 2015:1). Diğer bir anlatım ile sayısal çoğunluk olmadan yönetimi elinde bulundurmak olumsuzluğu demokrasi açısından sorun oluşturmakta olduğu gerçeğinin yanında elitlerin yönetim tecrübesinin ve yetişmişliğinin göz ardı edilmemesi gerekmektedir.

\section{YEREL ELITLER}

Yerel elitler aynı zamanda kentsel elitler olarak da ifade edilmektedir. Bu kesim, kentteki politika ve programlar üzerinde belirleyici bir etkiye sahip olan aktörlerden oluşmaktadır. Kentsel elitler parçalanmış şekilde olabilirler ancak belirli bir siyasi gündemin ilerletilmesinde ortak bir çıkarla bir araya gelmekten çekinmezler. Bu arzu, diğer sosyal katmanları kontrol altında tutmayı ve hüküm süren hükümleri meşru kılan görüşlerle telkin etmeyi amaçlayan çok sayıda kurumsal yolla yerine getirilmektedir. Kentsel elitlerler yüksek cinsiyetlendirilmiş, ırksallaştırılmış ve kentsel alanda ayrıştırılmış bir durumda olabilirler. Çok boyutlu ve çok yönlü güç hiyerarşilerine dâhil edildiklerinden, kentsel elitler gittikçe daha fazla ulusötesi elitlerin bir parçası olurken daha yüksek veya daha düşük ölçeklerdeki aktörlerle çatışabilirler. Kentsel elitlerin varlı̆̆ kaçınılmazdır ve zorunlu olarak istenmeyen bir durum değildir, ancak kendilerini sürdürme ve kendi özlemlerini teşvik etme biçimleri diğer sosyal grupların çıkarlarıyla çelişebilir ve çoğu zaman devam eden normatif tartışmaların odağ olabilmektedir (Gyuris, 2017:7334).

Elitlerin tüm hükümet birimlerine etki etmesi veya onları ele geçirmesi bağlamında değerlendirildiğinde yerel birimlerin daha hassas olduğu aşikârdır. Bu çerçevede Bardhan ve Mookherjee'ye (1999:11) göre, devletin seviyesi halk nezdinde ne kadar yerelse, belli gruplar tarafından ele geçirilmesi o kadar kolaydır. Bu durumda dezavantajlı gruplar o kadar az korunmaktadır. Bu bağlamda değerlendirildiğinde toplum ne kadar küçük olursa, o kadar az farklı siyasal grup ve onu oluşturan çıkarlar o kadar az olacaktır. Farklı partiler ve çıkarlar ne kadar azsa, aynı partide çoğunluk o kadar sık bulunur ve çoğunluğu oluşturan birey sayısı ne kadar küçükse ve yerleştirildikleri pusula ne kadar küçükse, baskı planlarını o kadar kolay birleştirir ve uygularlar. Birçok bilim insanı yerel yönetimlerin belli bir grup (elitlerin) tarafından ele geçirilmesine karşı savunmasız olduklarını vurgulamaktadır. Çünkü katılımcılar sürece eşit olmayan güç konumlarından girmektedir. Bu durumları şu şekilde sıralanabilir (Khan, 2008:512);

- Asimetrik sosyal konumlar,

- Ekonomik kaynaklara farklı erişim,

- Değişen siyasi protokol ve prosedür seviyeleri,

- Farklı okuryazarl1k oranları.

UNDP'nin İnsani Gelişme Raporu (1993), âdemi merkeziyetçiliğin yerel elitlere yerel nüfustan daha fazla güç verebileceği durumuna değinmiştir. Benzer görüsşler daha yakın zamanlarda dile getirilmiştir. Örneğin, Mansoori ve Rao (2004), yerel seçimlerin yerel kurumlara nasıl egemen olduğunu, yerel elitler ve yoksul insanların, zayıf sosyal ve ekonomik nedenlerinden dolayı sistematik olarak katılımcı süreçten nasıl dışlandığı üzerinde durmaktadırlar.

Huque (2002:1), küçük bir elit grup tarafından yerel kurumlar üzerinde kontrol ve tahakküm tutma eğiliminin kalıc1 olduğuna vurgu yapmaktadır. Dünya Bankası (2001:106), âdemi merkeziyetçiliğin elitlerin gücünü arttırabileceği ve eşitliği kolaylaştırmak yerine - katılım, temsil, etki, fayda paylaşımında etkili olmak üzere ek 
baskı araçlarının temin edilmesine yol açabileceği konusunda uyarırlar yapmıştır. Elitlerin bu egemenliği elde etmesi veya ele geçirilmesi, yerel yönetimlerin halkın ihtiyaçlarına, özellikle de fakir insanların ihtiyaçlarına daha az yanıt vermesine neden olabilir (UNDP, 1998:56). Elitlerin yönetimi ele alması, yerel yönetimin, seçkin olmayanların pahasına yerel elitlere hizmet sunma eğilimine neden olabilir (Platteau, 2003:225-227). Bu tahakküm, toplum temelli kalkınmanın savunucuları tarafından öngörülen geniş tabanlı demokratik katılımlara karşı çalışabilir, çünkü elitler tarafından hazırlanan kurallar, yoksul insanları yerel konseylere katılmaları bağlamında cesaretlerini kırabilir (Khan, 2008:513).

\section{6360 SAYILI KANUN}

Türkiye'de yerel yönetimler tarihi bir manada reformlar tarihidir. Ancak son on yıllık süre zarfinda bu reform ihtiyacı sürekli dillendirilmeye devam etmiştir. Merkez ve yerel yönetimler arasındaki çatışmalar genel itibariyle hem belediye yönetimlerinin işlevselliği üzerinde devam etmiştir (Erat, 2016:95). Zira demografik ve yönetsel kapasite bağlamında belediyeler büyük önem taşımaktadır. Belediyelerin etkin ve verimli çalışması ve demokrasiye uygun bir yönetim ile yönetilmesi arasındaki ince çizgi dönemsel olarak farklı yansımalara neden olmaktadır (Belli ve Aydın, 2012:137). Büyükşehir belediyeleri ise belediyeler arasında adından hareketle de yapılacak bir değerlendirme ile büyük bir öneme haizdir. Büyükşehir belediyeleri kanunda sınırları ve kıstasları ortaya koyan büyük yerleşim yerleri ile alakalı kentsel hizmetlerden mesul olmaları sebebiyle ön plana çıkmaktadır (Dağ ve Kılınç, 2017:429).

Genel olarak bakıldığında, Türkiye'de büyükșehir belediye yönetim modeli, 1984 yılı itibariyle 3030 sayılı yasa ile uygulanmaya başlanmıştır. Bu model özellikle Ak Parti iktidarına kadar olan dönemde belli değişikliklere uğramıştır (Zengin, 2014:95). 2002 yılı itibariyle başlayan Ak Parti iktidarı ile bu sorunlar daha çok dillendirilmiştir. Büyükşehir belediye başkanlığından gelen bir lider olan Recep Tayyip Erdoğan tarafından büyükşehir belediyesine yönelik sorunlar detaylı bir şekilde ortaya konularak bu konuda kamuoyu ile daha çok bilgi paylaşımında bulunulmuş ve çözüm odaklı yaklaşımlar arttırılmıştır. Yapılan küçük değişiklikler sonrası asıl köklü değişiklik 6360 sayılı kanun ile getirilmiştir. 2012 yılında kabul edilen ve akabinde yapılan ilk yerel seçimlerle uygulamaya konulan kanun, büyükşehir belediyeleri açısından getirmiş olduğu değişiklikler açısından büyük önem arz etmektedir. 6360 sayılı kanun birçok farklı noktadan değerlendirildiğinde bir dönüm noktası olmuştur. Özelikle büyükşehir belediye modelinin uygulanmaya başladığı tarihten itibaren öncelikle görev ve yetki dağılımı olmak üzere planlamadan, mali paylaşım ve benzeri gibi birçok önemli konuda problemle yüzleşmiş ve modelde bu zaman zarfında ciddi değişimler yapılmak zorunda kalınmıştır (Canpolat, 2010:45). Kanun 6 Aralık 2012 tarihinde yayımlanmış 6360 Sayılı "On Üç İlde Büyükşsehir Belediyesi ve Yirmi Altı İlçe Kurulması ile Bazı Kanun ve Kanun Hükmünde Kararnamelerde Değişiklik Yapılmasına Dair Kanun" ismi ile anılmıştır. Ancak daha sonrasında bir ilin eklenmesi ile 14 Mart 2013 tarihli ve 6447 sayılı Kanun'un 1. maddesiyle, bu Kanun'un başlı̆̆ında yer alan "On Üç" ibaresi "On Dört" olarak, "Yirmi Altı" ibaresi "Yirmi Yedi” olarak değiştirilmiştir (6360 say. Kanun, md.1).

6360 sayılı kanun büyükşehirlerin oluşumu ve yönetiminde farklı bir model anlayışını öngörmüş, illerdeki belediyelerin ve köylerin tüzel kişiliğinin kaldırılması gibi yerelde bazı önemli idari değişiklikler getirmiştir. Bunlara ek olarak, yasa ile 750.000'den fazla nüfusu olan iller büyükşehir belediyelerine dönüşmüştür (Yılmaz ve Sayın, 2018:1617; Belli ve Aydın, 2016:1699). Bu büyükşehirlerdeki belde belediyeleri ve köyler tüzel kişiliklerini kaybetti ve mahallelere dönüştürmüştür. Ayrıca büyükşehir belediye mücavir alanları eski dönemde İstanbul ve Kocaeli illerinde olduğu gibi tüm ile yayılmıştır. Bu çerçevede eskiden merkez ilçelerde olan yetkisizlik durumu tüm il düzeyine yaygınlaştırılmıştır. Aynı şekilde ilçe belediyelerin de mücavir alanı ilçe sınırlarına getirilmiştir. Diğer yandan nüfusu 2000'in altında olan ilçelerin kapatılmasına karar verilmiştir ${ }^{3}$.

\section{6360 SAYILI KANUN BAĞLAMINDA YEREL ELITTLERIN DEĞISŞIMİ}

6360 say1lı kanun ile ortaya çıkan yeni durum büyükşehirlerde yönetim, hizmetlerin götürülmesi, kent ve kentlilik kültürüne ciddi etkileri olmuştur. Kent ve kentlilik kültürü bağlamında değerlendirildiğinde yerel elitlerinde dönüştügünü veya değiştiğini söylemek mümkün olacaktır. Dolayısıyla yeni kanun Türk yerel yönetim tarihinde yeni bir dönemi başlatmıştır demek çok da iddialı bir yaklaşım olmayacaktır. Bunu ortaya çıkartan nedenler ise ilerleyen paragraflarda anlatılacaktır.

3 Sayılan başlıklar dışında da birçok değişikliğin olduğu aşikârdır. Ancak çalışmanın sınırlı yapısı gereği diğer başlıklara değinilmeyecektir. 
"Türk yerel yönetim tarihi reform tarihidir" ifadesi daha önce kullanılmış ve tepeden inmeci bir mantık ile gerçekleştiği anlatılmıştı. 6360 sayılı kanun ile merkezi yönetimin temel yapmak istediği hizmette etkinlik ve verimliliğin sağlanmasıdır. Bunu yaparken yerel özerklik ve subsidiarite temel ilkelerinden uzaklaşma durumu söz konusu olduğu aşikârdır. Ancak bunun tercih edilmesinin altında yatan temel neden hizmet sağlanması bağlamında özellikle küçük yönetimlerin düşmüş oldukları krizi çözmektir. Nitekim bu durum hizmetlerin daha büyük bir merkezden yapılarak çözüleceği fikrinden hareketle oluşturulmuştur. Öyle ki 6360 sayılı kanun ile beraber belde ve köylerin tüzel kişiliklerin kişiliklerinin kaldırılması ile köy ve belde belediyeleri yöneticilikler yok olmuştur. Köy muhtarlarının elinde olan ve genel itibariyle hiçbir seçilmiş veya atanmış yetkilide bulunmayan yetkiler ${ }^{4}$ ortadan kalkmıştır. Bu yüzden muhtarların yetkilerinin birçoğu kaybolmuş bir kısmı ise belediye yönetimlerine devredilmiştir. Bu durum ise köyler veya yeni ismi ile kırsal mahalleleri il veya ilçe merkezine daha bağımlı hale getirmiştir. Bir seçilmiş yerel elit olan muhtarlığın ağırlığı ortadan kısmen de olsa kalkmıştır.

Belde belediyelerin kapatılarak en yakın ilçe ile birleşmesi de yeni bir takım sorunları beraberinde getirmiştir. Birçok eski belde belediye başkanı belediye meclis üyeliklerine kaydırılmıştır. Bu da bir sorun teşkil etmektedir. Daha önce bir başkan olarak işlerini çözdüğü beldesinin sorunlarını daha çoklu bir ortamda icracı olarak değil ricacı olarak çözmeye çalı̧̧maktadırlar. Yani yerel elitler ilçe merkezinde sıradan siyasal figürlere dönüşmektedir. Ayrıca aralarında rekabet olan yakın ilçe ve beldelerin birleşmesi ve nüfusu çok olanın lehine hizmet yapılmaya neden olmaktadır. Yerel siyasal elitlerle belde düzeyinde karşılaşmak veya onlara ulaşılma noktasında halkın kolaylığı da zora girmiştir. Aynı şekilde ilçe merkezinde çözülen birçok işin il merkezine taşınması yüzünde yerel elitler bir manada ilçeden il merkezine taşınmak veya kaymak zorunda kalmışlardır. Öyle ki ana yönetim ve icra organına dönüşen büyükşehir belediye meclislerinin üyesi olarak ilçede ile taşınan yerel siyasal elitler yüzlerini ilçe belediyeden çok il merkezlerine çevirmiştir. Bu bağlamda yetkileri kısıtlanan ilçe belediye başkanlarının ağılığının il merkezi lehine azalması da elitlerin etkisini azaltan bir diğer unsur olmuştur.

İl merkezi ile ilişkileri iyi olan ve merkeze daha çok tesir edecek kişilerin tercih edilerek yönetime veya meclis üyeliğine kaydırılması yerel siyasal elitlerin dönüşümü noktasında diğer bir done olarak karşımıza çıkmaktadır. Oy potansiyeli yüzünden tercih edilerek il merkezine gönderilen meclis üyelerinin daha büyük bir siyasal arenada mücadele etmesi zor bir durumdur. Diğer yandan büyükşehir belediye meclis üyeleri seçim yöntemlerindeki adaletsizlik yüzünden ilçe nüfusları, sosyo-kültürel yapıları, ekonomik yapıları dikkate alınmadan belirlenememesi bir toplama yapı olan büyükşehir belediye meclislerinde il merkezlerinden olanları bir adım öne taşıyacaklardır. Bu durum ise ilçe ve belde düzeyindeki yerel siyasal elitlerin daralmasına ve sinırlanmasına neden olacaktır.

6360 sayılı kanun ile büyükşehir belediyelerinin görev ve sorumluluk alanları genişletilmiştir. Kanun çerçevesinde il mülki sınırlarını büyükşehir belediye sınırları ile özdeşleştirerek bütüncül yerel hizmet geliştirme çabasına gidilmiştir. Büyükşehir belediyeleri tarafından tek bir merkezden yürütülmesi sayesinde hizmet sunumunda etkinlik, verimlilik ve standartların yukarı taşınması, daha çok bilgi ve az kaynak ile yüksek kalitede hizmet sunulabilmeyi sağlaması açısından önem arz etmektedir (Yılmaz ve Kaypak, 2019:4; Belli ve Aydın, 2017:409). Fakat il merkezinin her hizmette başat güç olması il merkezlerindeki yerel siyasal elitleri bir adım ön plana çıkartmıştır. Artık yeni süreç ile yerel siyasal elitler il merkezi bağlamında yeniden şekillenmesine neden olmaya başlamış ve daha yerele rağmen il merkezi yerel siyasal elitleri avantajlı duruma gelmiştir.

\section{SONUC VE DEĞERLENDİRME}

Elitlerin varlığ kaçınılmaz ve önlenemez bir durum olarak değerlendirilmektedir. Bu durumu sadece olumsuz olarak ele almak siyaset bilimi açısından kolaya kaçmak olacaktır. Zira siyasal yerel elitlerin varlığı halkın yönetimle olan ilişkisini sağlaması başta olmak üzere birçok açıdan önem arz etmektedir. Türkiye'deki durumda da yerel demokrasinin sorunları göz önüne alındığında yerel halkın yerel temsilci olarak belirlediklerinin yerel siyasal elitlere dönüştüğü gerçeği söz konusudur. Uzun süredir belediye başkanlığı yapan kişilerin sayısının fazlalığı, bir kişinin yerel yönetimlerde birbirinden farklı birçok görevde bulunması, milletvekillerinin belediye başkanı olması veya belediye başkanlarının milletvekili olması gibi durumlar buna örnek olarak gösterilebilir. Sadece bireyler bazında değil belli gruplarında belli makamları tekellerinde tutması da aynı şekilde değerlendirilebilir. Nihayetinde bu durum Türk demokrasinin genel bir temsil ve katılım sorunudur.

4 Muhtarların kişisel vergi koyma, sosyal ve ekonomik düzen ile güvenliği sağlama ile halk ve devlet arasında köprü olmak gibi geniş yetkileri vard1. 
6360 sayılı kanun çerçevesinde yapılan genel değerlendirmede özellikle köy, belde ve ilçe düzeyindeki elitlerin daraldığı üzerinde durulmuştur. Bu durum genel çerçevede demokrasi açısından olumlu bir durum olarak gözükse de elitlerin halk ve yönetim arasında bir iletişim aracı olmaları durumu ortadan kalkmaktadır.

Yerelde daha demokratik bir yönetimler bütünü yerine daha iyi hizmet getiren yönetimler bütünü tercihi kanun temel noktasıdır. Bu tercih yerel siyasal elitlerin durumunu değiştirmeye başlamıştır. Artık yerel siyasal elitler kendine has yapıları ve kültürleri olan ilçelerin durumlarını ikinci plana atılarak il merkezi ön plana çıkmaktadır. $\mathrm{Bu}$ durum küçük boyutlu veya nüfuslu iller için sorun teşkil etmezken büyük iller için bir takım sorunları beraberinde getirecektir. Konya ili örneği durumun anlaşılması açısından önemli bir donedir. Konya coğrafi, ekonomik sosyal ve kültürel olarak devasa yapıda bir ildir. Konya'nın Ereğli, Akşehir, Beyşehir ve Seydişehir gibi il merkezine hem uzak hem de merkezden farklı sosyokültürel yapıya sahip yerlerin/kentlerin elitlerinin merkeze taşınarak il merkezinin kendi atmosferi içerisinde siyasal alanda kendilerini ifade etmeleri ilçe kökenli elitleri güçsüz kılacaktır. Bu güçsüzlük yerel demokrasinin tam oturmadığı Türkiye için ilçelerin haklarının daha iyi savunulması noktasında sorunlar oluşturabilecektir.

\section{KAYNAKÇA}

6360 sayılı On Dört İlde Büyükşehir Belediyesi ve Yirmi Yedi İlçe Kurulması İle Bazı Kanun ve Kanun Hükmünde Kararnamelerde Değişiklik Yapılmasına Dair Kanun (06.12.2012 tarih ve 28489 sayılı Resmi Gazete).

AKARD, Patrick (2001), "Social And Political Elites", Encyclopedia of Sociology, The Gale Group Inc., Michigan, https://www.encyclopedia.com/social-sciences/encyclopedias-almanacs-transcripts-andmaps/social-and-political-elites (Erişim Tarihi: 12.01.2019).

BARDHAN, Pranab ve MOOKHERJEE, Dilip (1999), "Relative Capture of Local and Central Governments: An Essay in The Political Economy of Decentralization", Center for International and Development Economics Research (CIDER) Working Papers, University of California-Berkeley, http://people.bu.edu/dilipm/wkpap/cap3.pdf (Erişim Tarihi: 12.01.2019).

BELLI, Aziz ve AYDIN, Abdullah (2017), "6360 Sayılı Kanun ve Yerelde Merkezileşme", International Journal of Social Science, S.55, ss.401-413.

BELLİ, Aziz ve AYDIN, Abdullah (2012), "Yerel Demokrasi ve Katılım: Kahramanmaraş ve Hatay Illerinin Karşılaştırılması", II. Bölgesel Sorunlar ve Türkiye Sempozyumu Bildiriler Kitabı, 1-2 Ekim, Kahramanmaraş Sütçü İmam Üniversitesi Yayını, Kahramanmaraş, ss.136-147.

BELLİ, Aziz ve AYDIN, Abdullah (2016), "6360 Sayılı Yasa ile Kapatılan Belde Belediyelerinin Hizmette Etkinlik ve Verimlilik Temsil Sorunsalı Üzerine Bir Alan Araştırmast: Önsen Belediyesi Örneği”, Uluslararası Sosyal Araştırmalar Dergisi, S.9 (43), ss.1698-1713.

CAMBRIDGE UNIVERSITY (1999), "Elite", Cambridge Dictionary, Cambridge University Press, Cambridge, https://dictionary.cambridge.org/dictionary/english/elite (Erişim Tarihi: 12.01.2019).

COLLINS ENGLISH DICTIONARY (2019), "Elite", Collins English E-Dictionary, https://www.collinsdictionary.com/dictionary/english/elite (Erişim Tarihi: 12.01.2019).

DAĞ, Mehmet ve KILINÇ, Furkan (2017), “6360 Sayılı Kanun Sonrası Büyükşehir Belediyeleri Açısından Mali Özerkliğin Değerlendirilmesi”, Bülent Ecevit Üniversitesi SBE Dergisi, S.6(2), ss.426-443.

ERAT, Veysel (2016), "Mahalli İdare Birimi Olarak Köyler ve 6360 Sayll Yasanın Etkileri", Bitlis Eren Üniversitesi Akademik İzdüşüm Dergisi, S.1 (1), ss.87-98.

GYURIS, Ferenc (2017), "Urban Elites March 2017", the International Encyclopedia of Geography, John Wiley \& Sons Publications, New Jersey, ss.7331-7351

HIGLEY, John, HOFFMANN-LANGE, Ursula, KADUSHIN, Charles ve MOORE, Gwen (1991), "Elite Integration in Stable Democracies: A Reconsideration", European Sociological Review, S.7 (1), ss.3553.

HUQUE, Ahmed Shafiqul (2002), "Participation and Development: A Balancing Act", "Participation for Global Action \& Change: Connecting Practitioners, Communities, Networks, Organizations", Konferans Sunumu, University of Guelph, 29 July-2 August - Canada ss.1-14. 
KHAN, Shadiullah (2008), "Local Governments and Local Elites", Local Government Studies, S.34 (4), ss.509-528.

LÓPEZ, Matias (2013), "Elite Theory", Sociopedia.isa, Rio de Janeiro, ss.1-12, http://www.sagepub.net/isa/resources/pdf/Elitetheory.pdf (Erişim Tarihi: 12.01.2019).

MALOY, Jason S. (2015), "Elite Theory", Encyclopadia Britannica, https://www.britannica.com/topic/elitetheory (Erişim Tarihi: 12.01.2019).

MANSURI, Ghazala ve RAO, Vijayendra (2004), Community-Based (And Driven) Development: A Critical Review, The World Bank, Washington, DC.

MICHELS, Robert (1915), 1959 Political Parties, Dover Publisher, New York.

MILLS, C. Wright (1956), the Power Elite, Oxford University Press, New York.

MONDAL, Puja (2019), "Political Elite: Concept, Orientations and Role in Social Change", E-Article, http://www.yourarticlelibrary.com/politics/political-elite-concept-orientations-and-role-in-socialchange/39204 (Erişim Tarihi: 12.01.2019).

MOSCA, Gaetano (1939), the Ruling Class, McGraw-Hill, New York.

OXFORD DICTIONARY (2016), "Elite", Oxford Dictionary, Oxford University Publisher, Oxford, https://en.oxforddictionaries.com/definition/elite (Erişim Tarihi: 12.01.2019).

PARETO, Vilfredo (1935), the Mind and Society, Harcourt Brace, New York.

PlATTEAU, Jean Philippe (2004), "Monitoring Elite Capture in Community-Driven Development", Development and Change, S.35 (2), ss.223-246.

TDK - TÜRK DİL KURUMU (2011), "Elit", Türkçe Sözlük, TDK Yayınları, Ankara, 11.Bask1, http://www.tdk.gov.tr/index.php?option=com_bts\&arama=kelime\&guid=TDK.GTS.5c5eed76072459.33 816513 (Erişim Tarihi: 12.01.2019).

UNDP (1993), Human Development Report 1993, Oxford University Press, Oxford.

UNDP (1998), Poverty Report 1998: Overcoming Human Poverty, United Nations Development Programme Publisher, New York.

URBAN DICTIONARY (2019), "Elite", Urban E-Dictionary, https://www.urbandictionary.com/define.php?term=Elite (Erişim Tarihi: 12.01.2019).

VOCABULARY.COM (2013), "Elite", Eocabulary $\quad$ E-Dictionary, https://www.vocabulary.com/dictionary/elite (Erişim Tarihi: 12.01.2019).

WEBER, Max (1978), Economy and Society, University of California Press, Berkeley.

WORLD BANK (2001), World Development Report 2000/1, the World Bank Publisher, Washington, DC.

YILMAZ, Vedat ve SAYIN, Ahmet Kenan (2018), "6360 Sayılı Yasa Sonrası İlçe Büyükşehir Belediyelerindeki Nüfus Değişimi Üzerine Bir Araştırma: Malatya Büyükşsehir Belediyesi”, Atlas Internatıonal Refereed Journal on Social Sciences, S.4(15), ss.1615-1627.

YILMAZ, Vedat ve KAYPAK, Şafak (2019), “6360 Sayılı Yasa Sonrası Yeni Büyükşehir Belediyelerindeki Çevre Sorunlarının Irrdelenmesi”, Kent Akademisi Dergisi, S.12(1), ss.1-28.

ZENGİN, Ozan (2014), "Büyükşsehir Belediyesi Sisteminin Dönüşümü: Son On Yılın Değerlendirmesi", Ankara Barosu Dergisi, S.72 (2), ss.91-116. 